\title{
An Investigation into Attitudes toward Physically Challenged Persons in Nepal: A Comparative Study with Japan
}

\author{
Fuyu Saito ${ }^{1, *}$, Haruka Yamashita ${ }^{2}$, Manita Shrestha $^{3}$, Masayuki Goto ${ }^{1}$ \\ ${ }^{1}$ School of Creative Science and Engineering, Waseda University, Japan \\ ${ }^{2}$ Faculty of Science and Technology, Department of Information and Communication Sciences, Sophia University, Japan \\ ${ }^{3}$ Tokyo Gakuge University, The United Graduate School of Education, Japan
}

Received July 3, 2019; Revised April 13, 2020; Accepted April 27, 2020

Copyright $\odot 2020$ by authors, all rights reserved. Authors agree that this article remains permanently open access under the terms of the Creative Commons Attribution License 4.0 International License

\begin{abstract}
There are serious problems with the increase of challenged persons in developing countries and we have to consider how to help them. Moreover, we also have to ask whether the Quality of Life (QOL) for them has actually improved. Do they feel despair over their real ambitions and are they content to be patient while in a state of unrealized potential? In other words, we have to have awareness not only how to deal with people who need help to live, but also how to make a society in which everyone can live independently and freely. In this research, we investigate the attitudes of Nepalese citizens who don't need a great support for living towards physically challenged persons and identify the problems with the current attitude of citizens towards them and discuss possible approaches and a vision for improving their QOL. To this end, we conducted a field survey in Nepal and Japan using a questionnaire, analyzed the data, and discussed to clarify the Nepalese awareness of physically challenged persons. In the end, we consider a possible solution to these problems from several viewpoints. By collecting data by various stratifications, it was found that there was a large difference in their awareness toward challenged persons by ethnic group, age, region, and gender as the major findings of the surveys. Also the Nepalese themselves are aware of the difference. Based on the above results, we point out that "unifying actual support and promoting citizens' awareness," "reviewing and strengthening the educational system," and "strengthening the leadership of the government to eliminate the differences between countries, genders, and caste groups" are three ways to address this issue. These three issues will have a positive effect on challenged persons in Nepal and also have a positive effect on society by reducing the burden on supporters.
\end{abstract}

Keywords Nepal, Physically Challenged Persons, Consciousness, Quality of Life

\section{Introduction}

Nepal, one of the most impoverished developing countries in South Asia, has many social issues, for example, poverty, the environment, and various gaps between ethnic groups. The various ethnic groups and castes are intricately intertwined with each other, and several issues occur because of Nepalese-specific race consciousness or social prejudices [1], [2], [3]. Especially, the discrimination against challenged persons is one of the biggest problems [4], [5], [6], [7], [8]. According to the Centers for Disease Control and Prevention, challenged persons are less likely to possess abilities that humans normally have [9]; therefore, they need support from other people or the social system in that all people can live with dignity and a high QOL is desirable. In order to realize this, the awareness of the people who support them is important. There are some articles which evaluates the appropriateness of existing approaches to the assessment of health-related quality of life (HRQOL) for challenged persons [10]. Against this background, this research presents a field survey in Nepal and an analysis of the data that were collected to obtain answers to research questions pertaining to the following issues:

1. To investigate the attitudes of Nepalese citizens towards physically challenged persons.

2. To identify the problems with the current attitudes towards physically challenged persons and discuss 
possible approaches and a vision for improving their QOL.

3. To discuss possible approaches and a vision for improving their quality of life.

Specifically, we investigate the impact of the perception of the challenged persons and report the differences in people's opinions based on factors like region, ethnicity, sex, and education. In addition, we conducted the same field survey in Japan and compared the results with those of Nepal. Ultimately, through this survey, we analyze the most influential political influences found in the questionnaire and consider possible solutions from several perspectives.

\section{Preliminaries}

\subsection{Basic Information about Nepal}

Nepal is a landlocked country in South Asia that is located between India and China, and there are eight of the world's ten tallest mountains, including Mount Everest, the highest point on Earth. Because of its geographic features, and the influence of the monarchy's closed policy, Nepal has become one of the most unique countries in the world. Furthermore, it is also unique because the large-scale migrations of Asian groups from Tibet (Autonomous Region of China) and Indo-Aryan people from northern India, which accompanied the early settlement of Nepal, have produced diverse linguistic, ethnic, and religious patterns. The total population of Nepal is 26.5 million. Among the population, the number of challenged persons is around 500 thousand, and $72 \%$ of the total number of challenged persons are physically challenged persons and the number of them is increasing (CBS, 2014) [11]. Furthermore, it is estimated that after the earthquakes in 2015, thousands of Nepalis were temporarily or permanently disabled through crush or other injuries and the number of challenged persons in Nepal has likely increased [12]. In Nepal, there have been many challenged persons whose existence is denied and hidden by not only the challenged persons themselves, but also their family members because of their several social/cultural/religious norms, beliefs, values, and pressures (Gabel \& Danforth, 2008) [13],[14]. For example, according to Hindu belief, it is said that, if a person is challenged, some Nepalese regarded it as a result of the sins of his/her past lives, and it is better not to have relationships with him or her. Against this background, especially among young people in urban areas and educated people, attitudes towards challenged persons are changing in Nepal. In fact, there had been articles reporting that an organization meant to make the public aware of the misery of female challenged persons was established [4], [14]. Sundar Shrestha advocates that advocacy by organizing for the social progress of challenged persons will solve many kinds of problems in Nepal [15]. In other words, by disseminating the awareness toward challenged persons so as to lead to improvement and organizing, it becomes possible to solve the problem of challenged persons, one of the many problems in Nepal.

\subsection{Literature Review}

Omonijo, D. O. has concluded that there was a significant relationship between the social perception of physically challenged persons and the attainment of life/personal goals [16]. Mizawa (1991) cites 5 important factors that are possible to say to be driven by individual awareness for improving the public's attitude towards challenged persons [17]. On the other hand, WHO indicates that the current awareness or understanding of challenged persons by non-challenged persons advances poorer health outcomes, lower educational achievements, less economic participation, higher rates of poverty or increased dependency, and restricted participation in society [14]. Therefore, the direction of public awareness toward challenged persons has a great impact on their Quality of Life. According to the World Bank, challenged persons are likely to experience a discriminatory attitude in the general areas of education, health, socio-economics, employment, and justice [18]. This discriminatory attitude has lowered the QOL for challenged persons and is now causing a number of existing problems actually. On the other hand, the QOL of challenged persons can be improved by making each person have the consciousness of questioning this issue, trying to understand challenged persons, and creating a society where challenged persons can live better. In fact, several concepts such as "universal design" that can be easily used by anyone have led to improvements in the QOL of many people, including challenged persons in developed countries [19], [20]. As mentioned above, the general public awareness of challenged persons directly leads to the QOL of them, so the WHO calls on member countries to raise awareness [21]. Despite this call, there are still some problems with challenged persons left to solve, especially in developing countries, and the improvement efforts are inadequate worldwide. In developing countries that have distinctive cultures and religious beliefs, such as Nepal, this trend is especially strong. Due to the reasons described above, support activities in Nepal with a high proportion of challenged persons should be improved, and we have to consider the awareness which is the most important components of all to translate this into action. On the other hand, in developed countries, the importance of the revolution in the awareness for physically challenged persons is being reconsidered, and countermeasures are being implemented to have an effect on many kinds of barriers that they tend to confront [22]. Japan is a developed country with relatively few religions and ethnic groups, and it can be said that the religious and ethnic 
influences on the difference in recognition of people with physically challenged persons are less than those of Nepal. Japan like that has paid attention to the importance of recognition of challenged persons at an early stage worldwide. For example, Haba, Y., \& Ogiwara, S. et al. have conducted a research to know certain statements about physically challenged persons and have suggested that physiotherapists should be aware of the gap in perception between the ideal attitude that health professionals would like their society to have and the reality [23]. In addition, they endeavored to promote a 'barrier-free' mind among members of the community and contributed to popularizing the awareness. Therefore, in this research, we would like to investigate the attitudes of Nepalese citizens who can have the opportunity to help physically challenged persons and identify problems with the current attitude of citizens towards them compared with Japan which has big different backgrounds with Nepal. Through the result of the field survey and citations of previous researches, we discuss possible approaches and a vision for improving their QOL.

\section{Research Method}

\subsection{Research Objectives}

Although there are many physically challenged persons who are living independently, this study focuses only on the awareness toward challenged persons who are difficult to live independently. In other words, in this research, we aim to investigate the attitudes of Nepalese supporters towards physically challenged persons who cannot live independently without the support and clarify if supporters' perceptions directly affect their lives. In addition, we identify problems with the current attitude of supporters towards these persons and discuss possible approaches and a vision for improving their QOL. To achieve these goals, we discuss with local university students and faculty members in Nepal and designed a questionnaire (see Appendix 1). To provide a frame of reference to point out problems, we did the research not only in Nepal but also in Japan, which is a developed country. In other words, we compare the results of research in Nepal and Japan to clarify the differences between them and discuss how to pursue approaches to addressing the issue. In this study, in order to focus only on physically challenged persons whose supporters' perceptions directly affect their lives, we defined the physically challenged persons as follows to distinguish them from many physically challenged persons who live independently.

A. People who have some physical limitations, including lack of mobility, dexterity, or stamina, or impairments such as blindness that may be present from birth or due to an accident and lack some normal abilities
(Note: Does not include mentally handicapped persons) [24].

B. People who cannot live independently without assistance but who can engage in work in an appropriate environment and with support.

In this research, the state that does not fit the definition of "physically challenged" is called "non-physically challenged". In addition, note that the blind is included in the physically challenged persons according to the definition in this study, although the blind tend to be generally referred to as "visually impaired" rather than "physically challenged". We designed a questionnaire to be administered in two localities in each country (see Appendix 1). It includes the following types of question items: (1) question items to ascertain the degree of connection with physically challenged persons, (2) question items to investigate their awareness, and (3) question items to ascertain their degree of experience with physically challenged persons.

Furthermore, the following question items are included in Section 2:

Q1. Attitudes towards physically challenged persons

Section 1: Reason that some people become physically challenged

Section 2: Emotions felt when seeing physically challenged persons

Q2. Existence of physically challenged persons

Q3. Necessity of the independence of physically challenged persons

Q4. Current status of the independence of physically challenged persons

Q5. Support for physically challenged persons

Q6. Comparison between the answers and the perceptions of others

This questionnaire included both the five-point Likert scale method (See Table 1) and multiple-choice and open-ended questions. In Sections 2-1 to 2-5(5), the five-point Likert scale was used. In Sections 2-5(6) to (11), multiple-choice questions were used. In Sections 1 and 3, open-ended questions were used to investigate the opinions of citizens directly. In addition, with respect to all questions from Sections 1 to 3 , we observe whether differences appear in response trends according to demographic attributes such as sex, caste, and job. This aims to clarify important factors indispensable to the situation in Nepal at the time. Through statistical analysis of the answers to the field interviews, we consider not only the situation but also the main problems. Finally, we consider the future tasks necessary to contribute to the development of Nepal in this area. For ease of understanding, we converted the scores of the answers to the questions as follows: 1 to $-2,2$ to $-1,3$ to 0,4 to 1 , and 5 to 2 (See Table 1). 
Table 1. Method of conversion

\begin{tabular}{|c|c|}
\hline Not at all & $1 \rightarrow-2$ \\
\hline Not so much & $2 \rightarrow-1$ \\
\hline Have no idea & $3 \rightarrow 0$ \\
\hline Agree & $4 \rightarrow 1$ \\
\hline Totally agree & $5 \rightarrow 2$ \\
\hline
\end{tabular}

\subsection{Method of Conducting the Field Interview}

In order to investigate attitudes towards challenged persons and the resultant real problems, we developed a questionnaire to investigate the current situation as well as people's awareness concerning challenged persons in Nepal and Japan. We conducted the interviews with a team of 40 people consisting of Nepalese and Japanese university students. Nepalese students carried out the interviews in Nepali, translating the responses to English. The research was conducted in the capital city of Kathmandu, Hetauda (a sub-metropolitan city in Nepal), Tokyo, and Shiga. The research was carried out from March 12 to 21 in Nepal and from April 1 to 20 in Japan in 2018. Through the method of random sampling, we interviewed a total of 191 citizens in Nepal and 86 citizens in Japan.

\section{Results and Discussion}

We targeted a total of 277 respondents, both male and female, in four areas, including shopkeepers, restaurant employees, hotel staff, students, farmers, and others. We focused on the awareness of challenged persons and differences in people's opinions from various perspectives such as region, caste, and sex. The ratios of sex, caste, region, and job category in this field study are shown in Table2 and 3.

Table 2 shows the distribution of countries. The percentage of Japanese respondents is lower. Table 3 shows the distributions of sex, regions, and caste of Nepal. This survey was conducted in two locations: the capital of
Kathmandu and Hetauda, which is a provincial city in Nepal [25]. Looking at the distribution of sex of the respondents, the percentage of males is slightly higher than that of females. In this survey, we were able to obtain responses from the following castes: Brahmin, Kshatriya, Vaishya and Sudra. These are from the Nepalese caste system consisting of four broad social classes called varna which is broadly borrowed [4],[26],[27].

Table 2. Distribution of the respondents according to country (\%)

\begin{tabular}{|l|c|c|}
\hline \multirow{2}{*}{ country } & Nepal & Japan \\
\cline { 2 - 3 } & 68.95 & 31.05 \\
\hline
\end{tabular}

Table 3. Distribution of the respondents according to sex, region and Caste in Nepal (\%)

\begin{tabular}{|c|c|c|c|c|}
\hline \multirow{2}{*}{ Sex } & Male & Female & \multicolumn{2}{|c|}{ Non-response } \\
\cline { 2 - 5 } & 57.59 & 41.36 & \multicolumn{2}{|c|}{1.04} \\
\hline \multirow{2}{*}{ Region } & Hetauda & Patan & \multicolumn{2}{|c|}{ Others } \\
\cline { 2 - 5 } & 38.74 & 60.73 & \multicolumn{2}{|c|}{0.52} \\
\hline \multirow{2}{*}{ Caste } & Brahmin & Kshatriya & Vaishya & Sudra \\
\cline { 2 - 5 } & 28.29 & 14.47 & 1.32 & 55.92 \\
\hline
\end{tabular}

\subsection{Analysis of the Averages and Standard Deviations of 5-Point Scale Questions}

\subsubsection{Differences between Nepal and Japan}

For the ordinal scale data, such as 2-1, 2-2, 2-3, 2-4 and 2-5(1) to (5), we calculated the average and standard deviation (SD) to capture the overall trend. Although it is not the best way to use SD for nominal and categorical data, this way is often used as a simplified method. For example, Kaplowitz, M. D., Hadlock, T. D., \& Levine, R. used SD in their analysis [27]. Table 4 shows the results of the average and SD of all of the 5-point Likert scale questions in Nepal and Japan. Looking at the table, it seems that there are trends in the absolute value of the average and standard deviation. 
Table 4. Attitudes towards physically challenged persons - The reason that some people become physically challenged persons -

\begin{tabular}{|c|c|c|c|c|c|}
\hline \multirow{2}{*}{ No } & \multirow{2}{*}{ Question } & \multicolumn{2}{|c|}{ Average } & \multicolumn{2}{|l|}{ SD } \\
\hline & & Nepal & Japan & Nepal & Japan \\
\hline \multicolumn{6}{|c|}{ 2-1. The awareness of the physically challenged persons } \\
\hline \multicolumn{6}{|c|}{ The reason why some people become physically challenged persons } \\
\hline $2-1-1(1)$ & It is because they committed a misdeed in previous lives. & -1.35 & -1.85 & 1.19 & 0.45 \\
\hline $2-1-1(2)$ & It is because it is a sacred destiny that god determines. & -0.86 & -1.45 & 1.50 & 0.98 \\
\hline $2-1-1(3)$ & It is because the nation has impurities. & -1.40 & -1.89 & 1.12 & 0.38 \\
\hline $2-1-1(4)$ & It is because the mother who gives birth to a physically challenged person has impurities. & -0.78 & -1.92 & 1.47 & 0.32 \\
\hline $2-1-1(5)$ & It is because the physical environment around the physically challenged persons is bad. & -0.28 & -1.35 & 1.48 & 1.01 \\
\hline $2-1-1(6)$ & It just happens by chance. There is no reason. & 0.38 & 1.23 & 1.50 & 1.12 \\
\hline \multicolumn{6}{|c|}{ The emotion when you see the physically challenged persons } \\
\hline $2-1-2(1)$ & You feel compassion (you think they are miserable). & 1.23 & -0.69 & 1.24 & 1.17 \\
\hline $2-1-2(2)$ & You feel jealousy because they take advantage of their disabilities. & -1.45 & -1.67 & 1.00 & 0.63 \\
\hline $2-1-2(3)$ & You feel uncomfortable. & -0.81 & -1.60 & 1.53 & 0.69 \\
\hline $2-1-2(4)$ & You think that we should respect them. & 1.55 & -0.70 & 0.74 & 1.05 \\
\hline $2-1-2(5)$ & You feel afraid. & -1.43 & -1.36 & 1.15 & 0.97 \\
\hline $2-1-2(6)$ & You feel nothing because you don't think they are special. & -0.82 & 0.36 & 1.27 & 1.08 \\
\hline \multicolumn{6}{|c|}{ 2-2. The awareness of the physically challenged persons } \\
\hline $2-2(1)$ & Physically challenged persons should not exist. & -1.03 & -1.60 & 1.48 & 0.86 \\
\hline $2-2(2)$ & $\begin{array}{l}\text { Physically challenged persons shouldn't go out; rather, they should stay in their homes as } \\
\text { much as possible. }\end{array}$ & -1.19 & -1.75 & 1.26 & 0.60 \\
\hline 2-2(3) & $\begin{array}{l}\text { If there were physically challenged persons in my family, I would want to hide them } \\
\text { from the world. }\end{array}$ & -1.62 & -1.62 & 0.97 & 0.64 \\
\hline $2-2(4)$ & If my child were born as a physically challenged person, it might be a trigger for divorce. & -1.46 & -1.17 & 1.05 & 0.99 \\
\hline $2-2(5)$ & $\begin{array}{l}\text { If my child were born as a physically challenged person, I would want to abandon } \\
\text { him/her if it were possible. }\end{array}$ & -1.69 & -1.59 & 0.84 & 0.81 \\
\hline $2-2(6)$ & I strongly desire not to be a physically challenged person. & -0.03 & 0.70 & 1.74 & 1.14 \\
\hline \multicolumn{6}{|c|}{ 2-3. The necessity of the independence of physically challenged persons } \\
\hline $2-3(1)$ & Physically challenged persons should be independent. & 1.10 & -0.22 & 1.14 & 1.08 \\
\hline $2-3(2)$ & $\begin{array}{l}\text { Physically challenged persons and able-bodied persons should cooperate with each other } \\
\text { in society. }\end{array}$ & 1.55 & 1.02 & 0.69 & 0.82 \\
\hline 2-3(3) & $\begin{array}{l}\text { There are jobs, such as simple tasks, that are better-suited to physically challenged } \\
\text { persons. }\end{array}$ & 1.18 & 0.71 & 0.96 & 0.97 \\
\hline 2-3(4) & $\begin{array}{l}\text { Physically challenged persons have the intellect or sensibility to come up with ideas that } \\
\text { get to the point. }\end{array}$ & 1.25 & 0.33 & 0.94 & 0.94 \\
\hline $2-3(5)$ & $\begin{array}{l}\text { Many physically challenged persons have abilities that are necessary for society, so we } \\
\text { should create an environment that makes good use of them. }\end{array}$ & 1.34 & 0.93 & 0.87 & 0.83 \\
\hline \multicolumn{6}{|c|}{ 2-4. The current status of the independence of physically challenged persons } \\
\hline $2-4(1)$ & $\begin{array}{l}\text { There are more independent physically challenged persons than dependent physically } \\
\text { challenged persons. }\end{array}$ & -0.19 & 0.00 & 1.40 & 0.95 \\
\hline $2-4(2)$ & $\begin{array}{l}\text { I am concerned about the quality of services and products produced by physically } \\
\text { challenged persons. }\end{array}$ & 0.40 & -0.80 & 1.35 & 0.97 \\
\hline 2-4(3) & $\begin{array}{l}\text { I have no problems with working in the same workplace as physically challenged } \\
\text { persons. }\end{array}$ & 1.01 & 0.96 & 1.25 & 0.93 \\
\hline \multicolumn{6}{|c|}{ 2-5. The support for physically challenged persons } \\
\hline $2-5(1)$ & Support is essential for physically challenged persons to be independent. & 1.56 & 1.02 & 0.60 & 0.95 \\
\hline $2-5(2)$ & $\begin{array}{l}\text { We can abolish challenges for physically challenged persons completely by, for example, } \\
\text { changing the means of providing support, arranging the environment to make things } \\
\text { easy, and designing products to be user-friendly. }\end{array}$ & 1.38 & 0.24 & 0.83 & 1.01 \\
\hline $2-5(3)$ & $\begin{array}{l}\text { If my child were a physically challenged person, I would expend all my time or effort to } \\
\text { help him/her. }\end{array}$ & 0.98 & 0.94 & 1.06 & 1.03 \\
\hline $2-5(4)$ & $\begin{array}{l}\text { If my child were a physically challenged person, there would be someone to take care of } \\
\text { my child besides me. }\end{array}$ & 0.42 & 0.84 & 1.35 & 0.95 \\
\hline $2-5(5)$ & $\begin{array}{l}\text { If family members (other than my child) or relatives had physical challenged persons, I } \\
\text { would like to actively support them. }\end{array}$ & 1.36 & 0.83 & 0.79 & 0.95 \\
\hline
\end{tabular}


Table 4 Continued

\begin{tabular}{|c|l|c|c|c|c|}
\hline \multicolumn{2}{|c|}{ 2-6. The comparison between the way you think for physically challenged persons and the way people around you think } \\
\hline $2-6(1)$ & $\begin{array}{l}\text { I think that my relatives have almost the same opinions as I do about physically challenged } \\
\text { persons. }\end{array}$ & 0.02 & 0.06 & 1.48 & 1.09 \\
\hline $2-6(2)$ & The way I think about physically challenged persons comes from my relatives. & -0.32 & -0.02 & 1.54 & 1.18 \\
\hline $2-6(3)$ & I want to discuss issues regarding physically challenged persons more with my relatives. & 0.96 & -0.32 & 1.09 & 1.04 \\
\hline $2-6(4)$ & I want to spread my ideas about physically challenged persons to the people around me. & 1.24 & -0.43 & 0.84 & 0.98 \\
\hline $2-6(5)$ & $\begin{array}{l}\text { I think that most Nepalese people have almost the same opinions as I do about physically } \\
\text { challenged persons. }\end{array}$ & -0.77 & -0.04 & 1.31 & 0.89 \\
\hline
\end{tabular}

Figure 1 shows a scatter diagram. The horizontal axis shows the absolute values of the averages, and the vertical axis shows the standard deviation. Looking at this graph, the black triangular points of Nepal tend to be to the left of, and farther up than, the gray circular points of Japan. So, in Nepal, the absolute values are smaller, and the standard deviation is larger than in Japan. This means that Nepalese citizens tend to have more varied opinions compared to the Japanese.

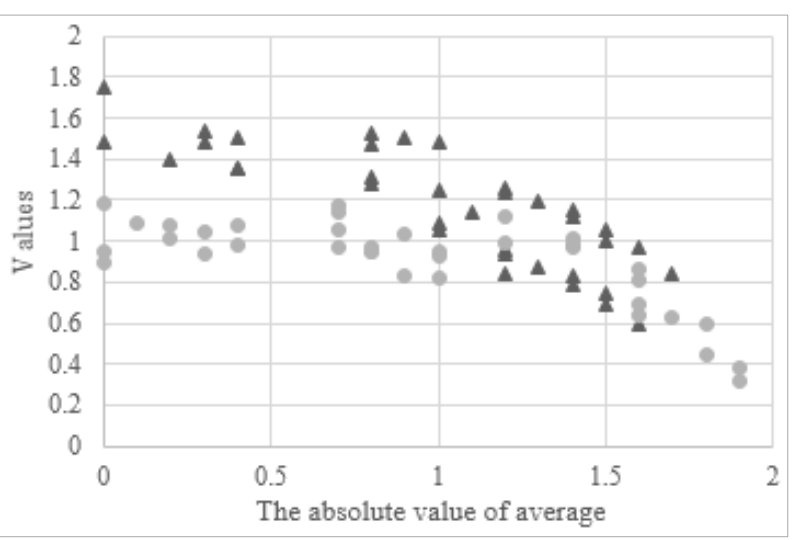

Figure 1. Scatter diagram showing the averages and standard deviations of all the 5-point scale questions

\subsubsection{Differences among Nepalese Citizens}

Next, we analyzed the differences among Nepalese caste. Therefore, we stratified the data by 4 caste groups, first. The stratification is based on research literature and interviews with Nepalese scholars and university students [26],[27].

1) Brahmin, which is the highest-ranking of the four social classes specializing as priests, teachers, and protectors of sacred learning.

2) Kshatriya, which is associated with warriorhood.

3) Vaishya, which is the third-ranking of the four social classes comprising mainly the merchants, business, or trade professions.

4) Sudra, which is the lowest rank of varna, and their occupational sphere stated as service of the other three varnas.

Table 5 shows the average of characteristic results when stratified by the 4 caste groups. We can see the various tendencies in their attitudes. Moreover, there are some items that received opposite answers.
Table 5. Average of characteristic results when stratified by the 4 caste groups

\begin{tabular}{|c|c|c|c|c|}
\hline & Brahmin & Kshatriya & Vaishya & Sudra \\
\hline $2-1-1(1)$ & -1.49 & -1.73 & -1.27 & -2.00 \\
\hline $2-1-1(2)$ & -1.16 & -1.14 & -0.74 & -2.00 \\
\hline 2-1-1(3) & -1.33 & -1.77 & -1.36 & -2.00 \\
\hline $2-1-1(4)$ & -0.98 & -0.95 & -0.90 & -1.50 \\
\hline $2-1-1(5)$ & -0.42 & -0.50 & -0.30 & -2.00 \\
\hline $2-1-1(6)$ & 0.51 & 0.18 & 0.65 & -0.50 \\
\hline $2-1-2(1)$ & 1.40 & 0.77 & 1.21 & 0.00 \\
\hline $2-1-2(2)$ & -1.40 & -1.59 & -1.32 & -1.50 \\
\hline 2-1-2(3) & -0.93 & -0.86 & -0.99 & -2.00 \\
\hline $2-1-2(4)$ & 1.67 & 1.64 & 1.49 & 1.50 \\
\hline $2-1-2(5)$ & -1.49 & -1.27 & -1.48 & -2.00 \\
\hline $2-1-2(6)$ & -1.12 & -0.68 & -0.64 & -2.00 \\
\hline $2-2(1)$ & -0.81 & -1.00 & -1.06 & 0.00 \\
\hline $2-2(2)$ & -1.00 & -1.36 & -1.14 & -2.00 \\
\hline $2-2(3)$ & -1.56 & -1.86 & -1.54 & -2.00 \\
\hline $2-2(4)$ & -1.35 & -1.77 & -1.43 & -2.00 \\
\hline $2-2(5)$ & -1.65 & -1.77 & -1.61 & -2.00 \\
\hline $2-2(6)$ & -0.07 & -0.68 & 0.19 & -1.00 \\
\hline $2-3(1)$ & 1.07 & 1.41 & 1.06 & 1.50 \\
\hline $2-3(2)$ & 1.63 & 1.64 & 1.54 & 1.50 \\
\hline $2-3(3)$ & 1.00 & 1.18 & 1.27 & 1.50 \\
\hline $2-3(4)$ & 1.19 & 1.27 & 1.23 & 1.00 \\
\hline $2-3(5)$ & 1.33 & 1.32 & 1.37 & 1.00 \\
\hline $2-4(1)$ & -0.65 & -0.09 & -0.15 & -0.50 \\
\hline $2-4(2)$ & 0.23 & 0.55 & 0.32 & 1.50 \\
\hline $2-4(3)$ & 1.00 & 0.95 & 1.04 & 1.50 \\
\hline $2-5(1)$ & 1.65 & 1.59 & 1.54 & 1.00 \\
\hline $2-5(2)$ & 1.31 & 1.55 & 1.36 & 1.00 \\
\hline $2-5(3)$ & 0.86 & 1.18 & 0.82 & 1.50 \\
\hline $2-5(4)$ & 0.77 & 0.41 & 0.48 & 1.50 \\
\hline $2-5(5)$ & 1.28 & 1.50 & 1.35 & 1.50 \\
\hline $2-6(1)$ & -0.12 & 0.68 & 0.19 & 1.50 \\
\hline $2-6(2)$ & -0.31 & 0.64 & -0.41 & -0.50 \\
\hline $2-6(3)$ & 0.74 & 0.91 & 0.96 & 1.50 \\
\hline $2-6(4)$ & 1.33 & 1.36 & 1.11 & 1.50 \\
\hline $2-6(5)$ & -1.16 & -0.27 & -0.80 & -0.50 \\
\hline
\end{tabular}


We also analyzed the data with stratification by sex, country, and age, and we found some trends. The main findings are as follows:

Caste:

There are distinct tendencies stratified by caste.

Sex:

Males tend to have clearer images than females.

Region:

Citizens in urban areas tend to have negative images.

Age:

Some images change to negative/ positive as a person gets older.

We can suggest the following in view of these trends:

- A gap in the attitudes towards support and QOL of physically challenged persons

- The difficulty of unifying the policy of support for physically challenged persons

\subsection{Differences between Peoples' Images and Their Surroundings}

Next, we will show the results of an analysis of the differences between peoples' images and their surroundings.

Please see the average score of Section 2-Q6 for Nepalese and Japanese respondents in Table 4. Looking at questions No. 1, 2 and 5, we can see that the Nepalese tend to have more negative images than the Japanese. This shows that the Nepalese do not think that their opinions and opinions of others correspond. In other words, they realize that there is no "general opinion" of their nation, ethnicity, or relatives in Nepal. Looking at the averages of questions No. 3 and 4, the Nepalese tend to have more positive opinions of discussing and spreading their opinions than the Japanese. Therefore, we can infer that they want to discuss these issues with their relatives and spread their ideas about physically challenged persons. Moreover, because the correlation coefficient is 0.518 , the more they want to discuss these issues with others, the more they want to spread their own ideas.

To summarize the results of the questions regarding awareness of disagreements between their answers and the opinions of other people, we can say the following:

- Nepalese realize that there are no "Nepalese general opinions."

- There are many people who want to discuss their opinions about physically challenged persons with others.

- The more the Nepalese want to discuss these issues with others, the more they want to spread their own ideas.

From the results outlined above, we can conclude that, in Nepal, more and deeper discussion opportunities should be provided.

In fact, Dalal, A. K. and their research team had organized focus-group discussions taking physically challenged unemployed youths, their families and other community members. These helped in identifying the strengths of physically challenged applicants in India [28]. Although there are some differences between the groups of stratifications, Table 4 shows that the majority of every group tend to deny the discriminatory or negative ideas for physically challenged persons.

Therefore, by sharing the opinions between various persons with different background, they can confirm the overall opinion such as "the discriminatory and negative ideas about physically challenged persons are old.” It will be possible to form public awareness in a positive direction.

\subsection{The Awareness of the Methods of Providing Support}

Next, we would like to explain the methods of providing support for physically challenged persons.

\subsubsection{Who Should Be the Leader?}

First, we will explain how the Nepalese think about who should lead efforts to support physically challenged persons. Table 6 shows the answer to the question, "Who should promote support activities for physically challenged persons?” of all the Nepalese answers.

Table 6. The ratio of each item for all respondents (\%)

\begin{tabular}{|l|r|}
\hline Category & Percentage \\
\hline Company & 2.09 \\
\hline Local community & 13.09 \\
\hline Local government & 12.57 \\
\hline Nation & 6.81 \\
\hline National government & 51.31 \\
\hline NGO & 7.85 \\
\hline Others & 6.28 \\
\hline
\end{tabular}

Furthermore, we stratified the data by caste groups, sex, or regions. By the stratification, for every type "Government" was the most frequent answer. Also, even when stratified by age, the percentage of the respondents who answered "Government" was the largest. From the previous chapter, it is obvious that there are great differences in awareness based on caste, sex, and age; therefore, this can cause differences in the actual level of support and the actual QOL for physically challenged persons. In this situation, we can conclude that government promotion of awareness can unify Nepalese efforts and reduce the gap between the QOL of physically challenged persons and that of non- physically challenged persons. In addition, to raise government awareness in Nepal, it is also necessary to improve awareness of measures for the physically challenged at the world level. In discussions with Nepalese students, there were many opinions that guidance and support from other developed countries often helped to improve policies in Nepal. On 
the other hand, Omonijo, D. O. pointed out that the Nigerian government in developing countries failed to implement the UN decisions on challenged persons due to several reasons [29]. This is because the government does not give a priority to the needs of physically challenged persons, the government does not respect the UN decisions, or the government does not have enough resources to implement the UN decisions[29]. Based on these discussions, the following can be pointed out.

- Decision, guidance, and support of policies by developed countries can be very effective for policy improvement in developing countries.

- If the support of developed countries is appropriate with a deep understanding of a target country, then the effect should be very useful. But, if a mismatch with the needs of the target country occurs, the effect will not be guaranteed.

In light of the above, careful policy decisions resulting from a deeper understanding of developing countries, including Nepal, and consideration at the global level that would have a profound impact on the improvement in the world are required.

\subsubsection{Which Supports Should Be Implemented to Enrich QOL?}

Next, we would like to explain how the Nepalese think about support for the physically challenged. Table 7 shows the answer to the question, "What type of support should we provide to improve the quality of life of physically challenged persons?" Looking at the results, $37 \%$ of all Nepalese answered "Education." Therefore, this should be the easiest department to improve to promote support for the physically challenged.

Table 7. The ratio of each item for all respondents (\%)

\begin{tabular}{|l|r|}
\hline Category & Percentage \\
\hline Categorical assistance & 12.57 \\
\hline Education & 36.65 \\
\hline Medical treatment & 27.75 \\
\hline Office & 3.14 \\
\hline Others & 4.19 \\
\hline Reformation of sense of challenged persons & 15.71 \\
\hline
\end{tabular}

This conclusion agreed with the analysis of Nepalese education conducted by Asada et al. (2017). In their analysis, a lack of satisfaction with the educational system by the Nepalese was suggested; therefore, the improvement of education for physically challenged persons could be a solution for improving the public's satisfaction with the educational system.

Many citizens are unsatisfied with the current educational system. Moreover, Asada et al. found that the educational system in Nepal lacks practical exercises, consisting of rote memorization and teacher-centered practices [30].

\subsection{The Emotions Felt When Seeing Physically Challenged Persons}

Next, we would like to discuss "The emotions felt when seeing physically challenged persons." Please see the average score of Section 2-1-2(1) to 2-1-2(6) for Nepalese and Japanese respondents in Table 4.

Looking at the results, we can see that the Nepalese do not feel negative emotions, such as "jealousy," "discomfort," or "fear." Instead, the Nepalese tend to feel compassion, pity, and that physically challenged persons are kind of "special."

Adding to the suggestion of Asada, practical experiences that would enable people to become familiar with physically challenged persons should be encouraged, for example, experience-based programs with wheelchair-bound or blind persons, as well as interaction with physically challenged persons.

Now, we present considerations and suggestions based on the results of the survey. Unifying support for, and awareness of, physically challenged persons should be a priority because it would enable us to implement activities to improve their lives in a unified way. In addition, efforts to improve support systems should be initiated by the government. Then, we could overcome the differences between countries, sexes, and caste groups. In countries like Nepal, national policies tend to be oriented towards the economy. However, it is also important to aim for a healthy society in which the economy, society, and the environment exist in harmony. In order to realize the ideal society, the government should take the initiative. Also, careful policy decisions resulting from a deeper understanding and consideration at the global level that would have a profound impact on the improvement of developing countries, including Nepal, are required. Education is also important. The educational system should dispel the lack of awareness of physically challenged persons and ideas that they are "special." Specifically, adding practical subjects to the curriculum and providing more and deeper discussion spaces with a variety of people of all caste groups, ages, and sexes are necessary. In doing so, we can unify Nepalese efforts and expect positive effects.

\section{Conclusions}

In this study, we investigated attitudes toward, and awareness of, physically challenged persons in Nepal using a questionnaire. Moreover, the differences in the tendencies of various demographics of respondents were compared and analyzed, stratifying by sex, caste group, age, and region. Through this investigation, the realities of the problem have been clarified. In addition, we have considered solutions for this problem. As a final suggestion, we point out that "unifying actual support and promoting citizens' awareness," "reviewing and 
strengthening the educational system," and "strengthening the leadership of government to eliminate the differences between countries, genders, and caste groups" are three ways to address this issue. In the future, it would be desirable to broaden the survey target from physically challenged persons to mentally challenged persons or individuals with sensory defects. Another future goal might be to explore the attitudes of the physically challenged towards their own condition. It is desired to conduct a survey for the physically challenged in order to investigate the correlation between satisfaction with quality of life and the attitudes towards individual condition. Through the survey, we can expect to clarify what perceptions are effective in improving. For example, we might measure the effect of support activities provided by organizations or the effect of the belief that physically challenged persons are "special."

\section{Acknowledgements}

We are very grateful to the following experts for their appropriate and constructive suggestions to improve this research paper. The authors would like to acknowledge Mr. Ujjwal Upadhyay, National College, Kathmandu; Prof. Brenda Bushell, University of the Sacred Heart; and Mr. Shuji Yagyu, Graduate University for Advanced Studies, for their useful suggestions and cooperation with our research. The field interviews were conducted with the support of the students at National College, which is affiliated with Kathmandu University. We would like to thank all the students who supported our research.

Besides, we are very grateful to Ms. Sae Iwata; Mr. Yushi Saito, Waseda University; Ms. Mizuki Itabashi; Ms. Risa Kagawa, University of the Sacred Heart; and the members of the Nepal Japan Project team for their helpful comments on this research.

\section{Appendix 1}

Date:

No.

Interviewer:

Place:

\section{Questionnaire about the Awareness of the Physically Challenged Persons in Nepal}

Name:_Family structure: _Sex: M/FAge: Caste or Ethnic background: Highest level of education: $\square$ elementary school education $\square$ lower secondary education $\square$ secondary education $\square$ higher education (school year:

Job: $\square$ farmer $\square$ shopkeeper $\square$ tourism $\square$ related to education(teacher) $\square$ student $\square$ others( )

Monthly income(Rps): $\square \sim 500 \square 501 \sim 1000 \square 1001 \sim 1,500 \square 1,501 \sim 2,000 \square 2,001 \sim 2,500 \square 2,500 \sim 3,000 \square 3,000 \sim$

\section{When You See the Words "Challenged Persons", Please Image the Following People}

- $\quad$ People who have some physical limitations, including lack of mobility, dexterity, or stamina, or impairments such as blindness, that may be present from birth or due to an accident, and lack some normal abilities (Note: does not include mentally handicapped persons)

- $\quad$ People who cannot live independently without assistance but who can engage in work in an appropriate environment and with support.

\section{Please tell us your connection with physically challenged persons}

1) How many persons do you

(1) see in a month (2) interact with in a month (3) are supporting now

2) If you interact with physically challenged persons, please tell us how they live their lives. 
2. For the following questions, circle the number that best matches your way of thinking about challenged persons (1: Not at all 2: Not so much 3 : have no idea 4: Agree 5: Totally agree)

1) The awareness of the physically challenged persons

\begin{tabular}{|l|l|l|l|l|l|l|}
\hline \multicolumn{2}{|l|}{ The reason why some people become physically challenged persons } & 1 & 2 & 3 & 4 & 5 \\
\hline 1 & It is because they committed a misdeed in previous lives. & 1 & 2 & 3 & 4 & 5 \\
\hline 2 & It is because this is the sacred destiny which god decides. & 1 & 2 & 3 & 4 & 5 \\
\hline 3 & It is because the nation has impurity. & 1 & 2 & 3 & 4 & 5 \\
\hline 4 & It is because the mother who gives a birth of a physically challenged person has impurity. & 1 & 2 & 3 & 4 & 5 \\
\hline 5 & It is because the physical environment around the physically challenged persons is bad. & 1 & 2 & 3 & 4 & 5 \\
\hline 6 & It is because of just by a chance. There are no reasons. & &
\end{tabular}

\begin{tabular}{|c|l|l|l|l|l|l|}
\hline 2. The emotion when you see the physically challenged persons & 1 & 2 & 3 & 4 & 5 \\
\hline 1 & You feel compassion (You think they are miserable). & 1 & 2 & 3 & 4 & 5 \\
\hline 2 & You feel jealousy because they take advantage of their disabilities. & 1 & 2 & 3 & 4 & 5 \\
\hline 3 & You feel uncomfortable. & 1 & 2 & 3 & 4 & 5 \\
\hline 4 & You think that we should respect them. & 1 & 2 & 3 & 4 & 5 \\
\hline 5 & You feel afraid. & 1 & 2 & 3 & 4 & 5 \\
\hline 6 & You feel nothing because you don't think they are special. & & \\
\hline
\end{tabular}

2) The awareness of the existence of physically challenged persons

\begin{tabular}{|c|c|c|c|c|c|c|}
\hline 1 & Physically challenged persons should not exist. & 1 & 2 & 3 & 4 & 5 \\
\hline 2 & Physically challenged persons shouldn't go out, but stay in their homes as much as possible. & 1 & 2 & 3 & 4 & 5 \\
\hline 3 & If there are familiar physically challenged persons, I want to hide them from the world. & 1 & 2 & 3 & 4 & 5 \\
\hline 4 & If my child is born as a physically challenged person, it can be trigger for divorce. & 1 & 2 & 3 & 4 & 5 \\
\hline 5 & If my child is born as a physically challenged person, I want to abandon him/her if it is possible. & 1 & 2 & 3 & 4 & 5 \\
\hline 6 & I strongly don’t want to be a physically challenged person. & 1 & 2 & 3 & 4 & 5 \\
\hline
\end{tabular}

3) The necessity of the independence of physically challenged persons

\begin{tabular}{|c|l|l|l|l|l|l|}
\hline 1 & Physically challenged persons should be independent. & 1 & 2 & 3 & 4 & 5 \\
\hline 2 & $\begin{array}{l}\text { Physically challenged persons and able-bodied persons should cooperate with each other in the } \\
\text { society. }\end{array}$ & 1 & 2 & 3 & 4 & 5 \\
\hline 3 & $\begin{array}{l}\text { There is job which the physically challenged persons are better at than the able-bodied persons such } \\
\text { as simple task }\end{array}$ & 1 & 2 & 3 & 4 & 5 \\
\hline 4 & $\begin{array}{l}\text { Physically challenged persons have intellect or sensibility to come up with the idea which gets to } \\
\text { the point. }\end{array}$ & 1 & 2 & 3 & 4 & 5 \\
\hline 5 & $\begin{array}{l}\text { Many physically challenged persons have the abilities which are necessary for society, so we should } \\
\text { make the environment to make good use of them. }\end{array}$ & 1 & 2 & 3 & 4 & 5 \\
\hline
\end{tabular}

4) The current status of the independence of physically challenged persons

\begin{tabular}{|c|c|c|c|c|c|c|}
\hline 1 & $\begin{array}{l}\text { There are more independent physically challenged persons than dependent physically challenged } \\
\text { persons. }\end{array}$ & 1 & 2 & 3 & 4 & 5 \\
\hline 2 & $\begin{array}{l}\text { I am concerned about the quality of services and products produced by physically challenged } \\
\text { persons. }\end{array}$ & 1 & 2 & 3 & 4 & 5 \\
\hline 3 & I have no problems about working with physically challenged persons in the same workplace. & 1 & 2 & 3 & 4 & 5 \\
\hline
\end{tabular}


5) The support for physically challenged persons

\begin{tabular}{|c|c|c|c|c|c|c|}
\hline 1 & Support is essential for physically challenged persons to be independent. & 1 & 2 & 3 & 4 & 5 \\
\hline 2 & $\begin{array}{l}\text { We can abolish the inconvenience of physically challenged persons completely by taking many ways, } \\
\text { for example, to change the way of support, to arrange the environment or to device the designs of } \\
\text { products to be user-friendly. }\end{array}$ & 1 & 2 & 3 & 4 & 5 \\
\hline 3 & If my child is a physically challenged person, I can spend all of my time or labor for him/her. & 1 & 2 & 3 & 4 & 5 \\
\hline 4 & $\begin{array}{l}\text { If my child is a physically challenged person, there is someone who takes care of my child except } \\
\text { myself. }\end{array}$ & 1 & 2 & 3 & 4 & 5 \\
\hline 5 & $\begin{array}{l}\text { If family members (other than your child) or relatives have physical challenged persons, I would like } \\
\text { to actively support them. }\end{array}$ & 1 & 2 & 3 & 4 & 5 \\
\hline
\end{tabular}

Select one item below you agree with most.

\begin{tabular}{|l|l|}
\hline 6 & If your child is a physically challenged person, which life do you think is enough for him/her to live? \\
\hline 1 & The life which he/she can satisfy physical needs. \\
\hline 2 & The life which he/she can satisfy safety needs. \\
\hline 3 & The life which he/she can satisfy love and belonging needs. \\
\hline 5 & The life which he/she can satisfy esteem needs. \\
\hline
\end{tabular}

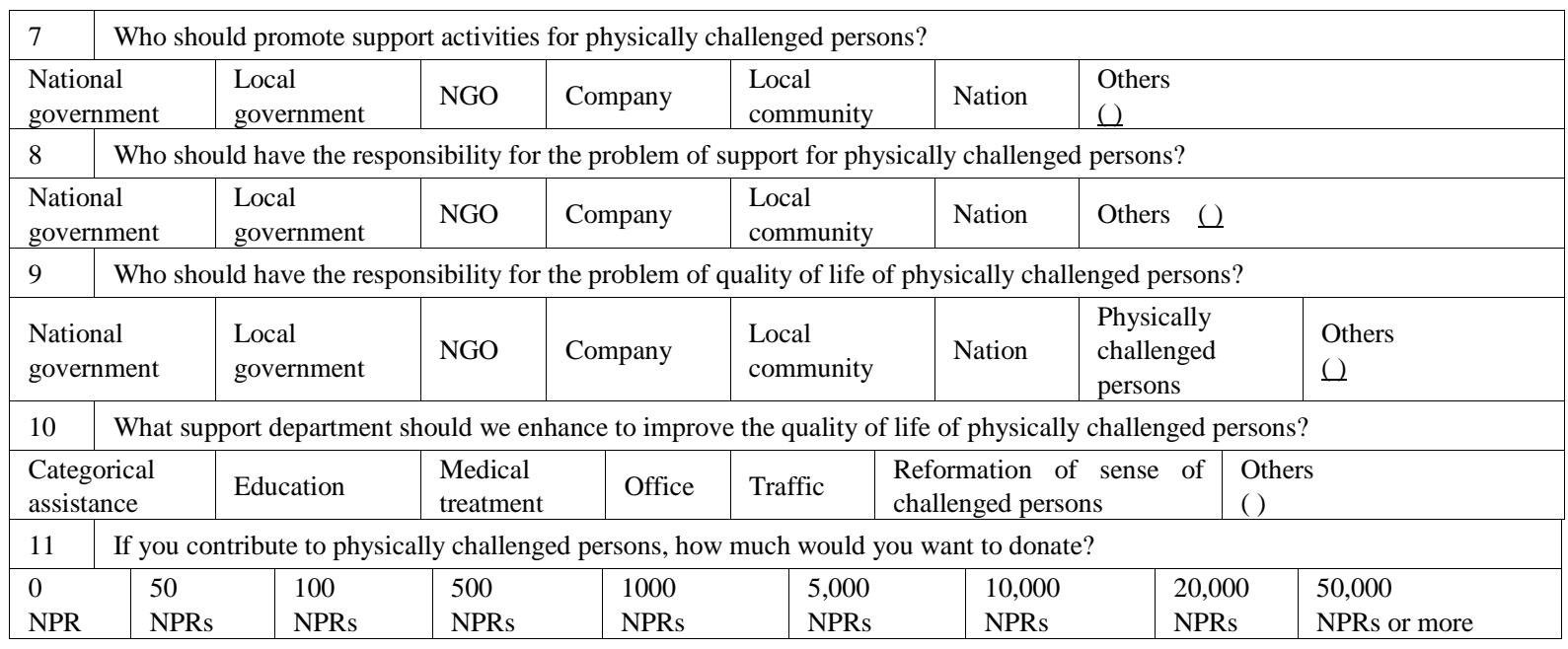

6) The comparison between the way you think for physically challenged persons and the way people around you think

(1: Not at all 2: Not so much 3: have no idea 4: Agree 5: Totally agree)

\begin{tabular}{|c|c|c|c|c|c|c|}
\hline 1 & I think that relatives have almost the same opinions as what I think for physically challenged persons. & 1 & 2 & 3 & 4 & 5 \\
\hline 2 & The way I think for physically challenged persons comes from my relatives. & 1 & 2 & 3 & 4 & 5 \\
\hline 3 & I want to discuss more about physically challenged persons with my relatives. & 1 & 2 & 3 & 4 & 5 \\
\hline 4 & I want to spread my ideas about physically challenged persons to the people around me. & 1 & 2 & 3 & 4 & 5 \\
\hline 5 & I think that the most Nepali people have almost the same opinions as me about physically challenged persons. & 1 & 2 & 3 & 4 & 5 \\
\hline
\end{tabular}

\section{Please answer the following questions}

1) Have you ever been helped by a physically challenged person? If you have, please tell us the situation in detail.

2) 3-2: Have you ever been educated about physically challenged persons? If you have, when and where?

3) Please tell us one or two of your concerns about the issues of the Quality of Life for the physically challenged persons in Nepal.

Thank you for your cooperation!! 


\section{REFERENCES}

[1] D.N. Gellner, Caste, Ethnicity and Inequality in Nepal, Economic and Political Weekly, Vol. 42, No. 20, 1823-1828, 2007.

[2] S.B. Christine Heward, Gender, Education and Development: Beyond Access to Empowerment, Zed Books, Vol. 12, No. 7, 224, 2000.

[3] D.R. Sharma, R.B. Thapa, H.K. Manandhar, S.M. Shrestha, S.B. Pradhan, Use of Pesticides in Nepal and Impacts on Human Health and Environment, Journal of Agriculture and Environment, Vol. 13, 67-74, 2012.

[4] B.M. Dhungana, The lives of disabled women in Nepal: vulnerability without support, Disability and Society, Vol. 21, No. 2, 133-146, 2006.

[5] S. lrudaya Rajan, Old Age Allowance Program in Nepal, Centre for Development Studies, Trivandrum, Kerala, India, 2003.

[6] K. Lamichhane, Employment Situation and Life Changes for People with Disabilities: evidence from Nepal, Disability and Society, Vol. 27, No. 4, 475-485, 2011.

[7] Centers for Disease Control and Prevention, Impairments, Activity Limitations, and Participation Restrictions, Centers for Disease Control and Prevention, 2017. Available at: https://www.cdc.gov/ncbddd/disabilityandhe alth/disability.html.

[8] S.B. Thapa, Perceived Needs, Self-Reported Health and Disability among Displaced Persons during an Armed Conflict in Nepal, Social Psychiatry and Psychiatric Epidemiology, Vol. 47, No. 4, 589-595, 2012.

[9] Central Bureau of Statistics - National Planning Commission Secretariat Government of Nepal, Nepal Living Standards Survey, Nepal Living Standards Survey Statical Report, Vol. 2, 1-193, 2011.

[10] Ronald D Hays, Harlan Hahn, Grant Marshall, Use of the SF-36 and Other Health-Related Quality of Life Measures to Assess Persons with Disabilities, Archives of Physical Medicine and Rehabilitation, Vol. 83, No 2, S4-S9, 2002

[11] M.P. Thapaliya, A Report on Disability in Nepal, Australian Himalayan Foundation (AHF), Sydney, Australia, 2016.

[12] Interactive map of disabled population in Nepal, 2016, Interactive map of disabled population in Nepal, Available at: https://codefornepal.org/2016/07/disability/

[13] T.R. Gautam, Migration and the Problem of Old Age People in Nepal, Dhaulagiri Journal of Sociology and Anthropology, Vol. 2, 145-160, 2008.

[14] M. Banskota, Nepal Disability Policy Review, Disability Research Center, School of Arts, Kathmandu University.

[15] S. Shrestha, Challenges in The Inclusion of People with Disability in Nepalese Society, Faculty of Social Sciences, University of Nordland, Norway, 2015.

[16] Omonijo, D. O., Impacts of Societal Prejudice on Attainment of Life/Personal Goals of Physically Challenged Persons in Nigeria. International Research Journal of Humanities, Vol 4, No 5, 1-14, 2012

[17] L.M. Rees, O. Spreen, M. Harnadek, Do Attitudes towards Persons with Handicaps Really Shift Over Time? Comparison between 1975 and 1988, Mental Retardation, Vol. 29, No. 2, 81-86, 1991.

[18] Specializing in Commercial Grade Pool Lifts, The Importance of Disability Awareness and Getting Involved, Available at http://www.globalliftcorp.com/the-importance -of-disability-awareness-and-getting-involved/

[19] Dolan, R., Hall, T. E., Banerjee, M., Chun, E., \& Strangman, N., Applying Principles of Universal Design to Test Delivery: The Effect of Computer-based Read-aloud on Test Performance of High School Students with Learning Disabilities, The Journal of Technology, Learning and Assessment, Vol. 3, No 7, 2005.

[20] Douglas E. Crews, Susan Zavotka, Aging, Disability, and Frailty: Implications for Universal Design, Journal of physiological anthropology, Vol. 25, No 1, 113-118, 2006.

[21] WHO Disability and Health Available at: https://www.who. int/news-room/fact-sheets/detail/disability-and-health

[22] World Health Organization, World Report on Disability: Summary, World Report on Disability, 2011.

[23] Haba, Y., \& Ogiwara, S., Attitudes of the citizens of Kanazawa and its vicinity towards the physically challenged. Journal of Physical Therapy Science, Vol 13, No 2, 107-113, 2001

[24] Nepal Government, Definition and Classification of Disability in Nepal, Nepal Government, Nepal, 2006.

[25] P. Kauda, Hetauda, ECS NEPAL, 2012. Available at: http://ecs.com.np/features/hetauda.

[26] Caste system in Nepal - Wikipedia, Available at: https://en.wikipedia.org/wiki/Caste_system_in_Nepal

[27] Kaplowitz, M. D., Hadlock, T. D., \& Levine, R. A comparison of web and mail survey response rates. Public opinion quarterly, Vol 68, No 1, 94-101, 2004

[28] Dalal, A. K., Social interventions to moderate discriminatory attitudes: the case of the physically challenged in India. Psychology, health \& medicine, Vol 11, No 3, 374-382., 2006

[29] Omonijo, D. O., Impacts of Societal Prejudice on Attainment of Life/Personal Goals of Physically Challenged Persons in Nigeria. International Research Journal of Humanities, Vol 4, No 5, 1-14., 2012

[30] M. Asada, An Investigation into the Awareness of the Need for Quality Education in Nepal, Japan Individual Management Association, 44-45, 2017. 